\title{
Apparent nutrient digestibility and mineral availability of protein-rich ingredients in extruded diets for Nile tilapia ${ }^{1}$
}

\author{
Igo Gomes Guimarães ${ }^{1}$, Luiz Edivaldo Pezzato², Margarida Maria Barros², Rosângela do \\ Nascimento Fernandes ${ }^{3}$
}

\footnotetext{
${ }^{1}$ Universidade Federal de Goiás, Departamento de Zootecnia, Jataí, Goiás, Brasil.

2 Departamento de Melhoramento e Nutrição Animal, Faculdade de Medicina Veterinária e Zootecnia - UNESP, Botucatu, SP. Brasil.

${ }^{3}$ Doutoranda do PPG em Aquicultura do Centro de Aquicultura da UNESP - CAUNESP, Jaboticabal, SP, Brasil.
}

\begin{abstract}
Apparent digestibility coefficients (ADC) of gross energy and dry matter (DM) and mineral availability were evaluated for eight protein-rich ingredients (corn gluten meal, soybean meal, cottonseed meal at 280.0 and $380.0 \mathrm{~g} / \mathrm{kg}$, poultry by-product meal, meat meal, fish meal and feather meal) in compound diets for Nile tilapia. Chromic oxide was used as inert digestibility marker. Higher ADC values of DM and energy were, respectively, 0.862 and 0.881 for corn gluten meal, 0.811 and 0.888 for poultry by-product meal; 0.729 and 0.731 for feather meal; 0.666 and 0.754 for fish meal; 0.578 and 0.642 for soybean meal; 0.476 and 0.652 for meat meal at $450.0 \mathrm{~g} / \mathrm{kg} ; 0.352$ and 0.449 for cottonseed meal at $380 \mathrm{~g} / \mathrm{kg}$; and 0.251 and 0.324 for cottonseed meal at $280.0 \mathrm{~g} / \mathrm{kg}$. The highest average mineral availability was for poultry by-product meal $(0.582)$, and the lowest calcium and phosphorus availability were recorded for cottonseed meal at $280.0 \mathrm{~g} / \mathrm{kg}$. Therefore, poultry by-product meal appears to be the best ingredient for using in Nile tilapia diets.
\end{abstract}

Key Words: calcium, feed evaluation, gross energy, nutritional value, Oreochromis niloticus, phosphorus

\section{Introduction}

Besides the importance of minerals to proper fish growth performance and resistance to disease, their role on the environmental impact of aquaculture has been addressed. Although other components of feeds are considered, phosphorus $(\mathrm{P})$ and nitrogenous $(\mathrm{N})$ outputs are the main chemical elements regarding attention to the eutrophication of water bodies. Based on this, Persson (1991) warned for the release of solid wastes, $\mathrm{P}$ and $\mathrm{N}$ from aquaculture operations to the ecosystems.

Consequently, several authors have been studying and proposing models and management practices to reduce and/or predict aquaculture waste outputs aiming to improve the activity sustainability (Cho \& Bureau, 2001; MacMillan et al., 2003; Tacon \& Forster, 2003; Hua et al., 2008; Sugiura et al., 2006). Among several approaches to limit the environmental impacts of feeds on aquaculture effluents, prescribing the minimum nutrient digestibility criteria and the use of plant protein sources with phytase in commercial feed diets have been emphasized (Powers-Hughes \& Soares Jr., 1998; Tacon \& Forster, 2003; Portz \& Liebert, 2004).
Several studies have reported nutrient digestibility in several feed ingredients for Nile tilapia, however, few studies have determined mineral availability. Recent studies have reported mineral availability in feed ingredients for European sea bass (Dicentrarchus labrax L.), Coho salmon (Oncorhynchus kisutch) and rainbow trout (Oncorhynchus mykiss) (Sugiura et al., 1998; Sugiura et al., 2000; Pimentel-Rodrigues \& Oliva-Teles, 2007).

Ingredients digestibility firstly depends on the chemical composition of feed ingredients and the digestive capacity. However, factors not related to diet formulation such as age, species, feeding management as well as feed processing methods could affect the nutrient digestibility values (Hepher, 1988; de la Higuera, 1987; McGoogan \& Reigh, 1996). Thus, several studies have reported the influence of feed processing on ingredients and diet digestibility (McGoogan \& Reigh, 1996; Gaylord \& Gatlin III, 1996; Sugiura et al., 1998; Pezzato et al., 2002; Sklan et al., 2004).

However, studies regarding the effect of extrusion on nutrient digestibility and mineral availability in feedstuffs for Nile tilapia are scarce. Thus, the objective of this study was to evaluate nutrient digestibility and 
mineral availability in eight protein-rich ingredients incorporated in extruded diets for this species.

\section{Material and Methods}

The reference diet (Table 1) was formulated to meet or exceed the nutrient requirements of Nile tilapia (NRC, 1993). Chromic oxide (Cr2O3) was used as external inert marker at $0.1 \%$ according to Bremer Neto et al. (2005). Test ingredients, vitamin and mineral premixes were supplied by Mogiana alimentos S.A.

Soybean meal, corn gluten meal, cottonseed meal 28 $(280.0 \mathrm{~g} / \mathrm{kg})$, cottonseed meal $38(380.0 \mathrm{~g} / \mathrm{kg})$, meat and bone meal, fish meal, poultry by-product meal and feather meal were evaluated in this experiment (Table 2). All ingredients were ground and mixed with the reference diet at a 7:3 ratio

Table 1 - Composition of the reference diet

\begin{tabular}{|c|c|}
\hline Ingredient & $\mathrm{g} / \mathrm{kg}$ \\
\hline Soybean meal & 575.0 \\
\hline Fish meal & 55.0 \\
\hline Broken rice & 274.0 \\
\hline Wheat middlings & 20.0 \\
\hline Soybean oil & 5.0 \\
\hline Vitamin premix ${ }^{1}$ & 1.0 \\
\hline Mineral premix ${ }^{2}$ & 3.0 \\
\hline Ascorbic acid & 0.8 \\
\hline Chromic oxide $\left(\mathrm{Cr}_{2} \mathrm{O}_{3}\right)$ & 1.0 \\
\hline L-lysine & 7.0 \\
\hline DL-methionine & 4.5 \\
\hline Threonine & 4.0 \\
\hline Dicalcium phosphate & 30.0 \\
\hline Limestone & 18.5 \\
\hline $\mathrm{NaCl}$ & 1.0 \\
\hline $\mathrm{BHT}^{3}$ & 0.2 \\
\hline \multicolumn{2}{|c|}{ 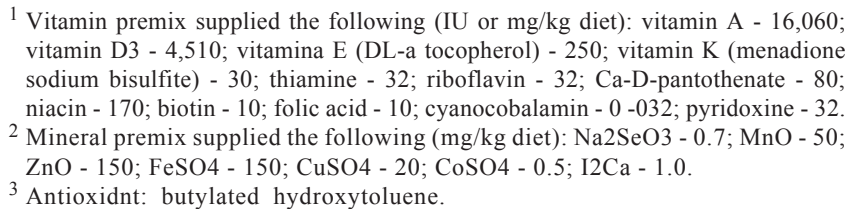 } \\
\hline
\end{tabular}

( $70 \%$ of reference diet to $30 \%$ of test ingredient). The concentration of chromic oxide was kept at $0.1 \%$ in all test and reference diets.

Diets were mechanically mixed with water ( $25 \%$ of dryweight) in a Kitchen Aid multi-function mixer and extruded at $99-120^{\circ} \mathrm{C}$ in a single screw laboratory extruder and exited in a $4.0 \mathrm{~mm}$ die aiming to obtain a $7.0 \mathrm{~mm}$ pellet diameter. Diets were oven dried and stored at $-18^{\circ} \mathrm{C}$ until used.

Nine compound diets were evaluated: eight containing the test ingredients and a reference practical diet. The reference diet was a soybean-broken rice based diets.

Nine $250 \mathrm{~L}$ aquaria were used for feeding procedure and, five conic $310 \mathrm{~L}$ aquaria were used to collect feces. Settlement column was used to perform this procedure. Both systems were connected to a biological filter and water temperature was maintained by thermostat-controlled heaters. The water was circulated at $6.59 \mathrm{~L} \mathrm{~min}^{-1}$ through aquaria and the temperature was maintained at $27.0 \pm 0.5^{\circ} \mathrm{C}$.

Fish with $96.6 \pm 3.1 \mathrm{~g}$ average weight were stocked at a density of twenty fish in each experimental unit (circular net cages inside the feeding aquaria). Firstly, 1,000 Nile tilapia fish were acquired from a commercial producer, from which 400 were selected by weight and reared in an indoor culture system at Aquaculture Research Nutrition Laboratory AquaNutri of São Paulo State University. These fish were fed with a growth ration produced in this laboratory until they reached the weight to begin the experiment. Then, 180 fish were selected by weight and distributed in nine net cages (groups of fish). Fish were handled in accordance with the guidelines approved by the Animal Care Committee of the Faculty of Veterinary Medicine and Animal Science.

Diets were randomly assigned to aquaria and fish were fed seven days prior to the beginning of fecal collection (acclimatization period), and the first collection of feces was carried out. For this collection, the first five groups of fish were transferred to collecting feces aquaria and on the consecutive day the remaining four groups were transferred

Table 2 - Proximate composition of test protein-rich feedstuffs and reference $\operatorname{diet}^{1}$

\begin{tabular}{|c|c|c|c|c|c|c|c|c|c|}
\hline Ingredient & CP $(\mathrm{g} / \mathrm{kg})$ & CL $(\mathrm{g} / \mathrm{kg})$ & GE (kcal/kg) & $\mathrm{Ca}(\mathrm{g} / \mathrm{kg})$ & $\mathrm{P}(\mathrm{g} / \mathrm{kg})$ & $\operatorname{Mg}(g / k g)$ & $\mathrm{Cu}(\mathrm{mg} / \mathrm{kg})$ & CF $(\mathrm{g} / \mathrm{kg})$ & Ash $(\mathrm{g} / \mathrm{kg})$ \\
\hline Soybean meal & 512.1 & 14.8 & 3990 & 2.7 & 6.2 & 2.7 & 18.3 & 71.2 & 74.4 \\
\hline Corn gluten meal & 700.7 & 94.8 & 4926 & 0.2 & 3.1 & 0.3 & 4.6 & 8.3 & 17.0 \\
\hline Cottonseed meal-28 & 333.7 & 17.7 & 4183 & 1.6 & 7.9 & 4.6 & 8.0 & 196.8 & 57.2 \\
\hline Cottonseed meal-38 & 375.2 & 32.8 & 4177 & 2.0 & 9.0 & 4.8 & 50.0 & 163.7 & 59.3 \\
\hline Local fish meal & 574.1 & 86.1 & 3200 & 81.9 & 31.5 & 2.4 & 9.2 & - & 337.7 \\
\hline Meat and bone meal & 473.0 & 89.0 & 3133 & 132.0 & 61.8 & 2.6 & 10.5 & - & 413.4 \\
\hline Poultry by-product meal & 627.9 & 171.2 & 4864 & 34.6 & 20.6 & 1.5 & 9.7 & - & 183.0 \\
\hline Poultry feather meal & 865.3 & 81.3 & 5574 & 2.2 & 1.6 & 0.3 & 11.7 & - & 27.5 \\
\hline Reference diet & 367.7 & 40.2 & 4235 & 22.7 & 12.1 & 2.6 & 52.0 & 40.2 & 111.2 \\
\hline
\end{tabular}

CP - crude protein; CL - crude lipid; GE - gross energy; Ca - calcium; P - phosphorus; Mg - magnesium; Cu - copper; CF - crude fiber.

${ }^{1}$ Dry-matter basis. 
and feces collected. This procedure was carried out until a representative volume of feces for a replication (each group of fish) to perform chemical analysis was collected. Test diets were then reassigned to the net cages for each following round. After the first round, the acclimatization period for each test diet was reduced to four days to avoid any adaptative fish response and to allow evacuation of previously ingested feed, as recommended by Sugiura et al. (1998). On the collecting day, fish were fed twice in the morning, and every hour in the afternoon. The acclimatization and fecal collection processes (round) were repeated four times to obtain quadruplicate measurements per treatment (test diets).

The cages were transferred to separate aquaria for collection of feces at 18:00, where they remained until the morning of the following day, in order to avoid the presence of feed in the fecal samples, as previously reported (Pezzato et al., 2002). Then, the cages were returned to the respective feeding aquaria. Feces were oven-dried at $55^{\circ} \mathrm{C}$, ground and stored at $-20{ }^{\circ} \mathrm{C}$ until chemical analysis.

Chemical analysis of feedstuffs, diets, and feces were performed according to AOAC (1995) protocols. Samples were analyzed to determine calcium $(\mathrm{Ca})$, phosphorus $(\mathrm{P})$, magnesium $(\mathrm{Mg})$ and copper $(\mathrm{Cu})$ concentrations by flame atomic absorption spectrophotometry on a Shimadzu AA6800 (Shimadzu, Japan). The chromic oxide content of diets and feces was determined according to Bremer Neto et al., (2005) and the gross energy content was determined in an adiabatic calorimetric bomb (Parr Instrument Company, Moline-IL, USA).

Apparent digestibility coefficients (ADC) for test diets were calculated according to equation described by Cho (1993):

$$
A D C_{(n)}=100-\left[100\left(\frac{\% \mathrm{Cr}_{2} \mathrm{O}_{3 d}}{\% \mathrm{Cr}_{2} \mathrm{O}_{3 f}}\right) \times\left(\frac{\% N_{f}}{\% N_{d}}\right)\right]
$$

in which ADC (n) = apparent digestibility coefficients of a nutrient in the test diets; $\mathrm{Cr} 2 \mathrm{O} 3 \mathrm{~d}=\%$ chromic oxide of the diet; $\mathrm{Cr} 2 \mathrm{O} 3 \mathrm{f}=\%$ chromic oxide of the feces; $\mathrm{Nd}=$ nutrients in the test diet; $\mathrm{Nf}=$ nutrients in feces.

Apparent digestibility coefficients of nutrients from each ingredient were calculated according to the equation proposed by Forster (1999).

$$
A D C N_{\text {ing }}=\frac{\left[(a+b) \times A D C N_{\text {test }}-a \times A D C N_{\text {ref }}\right]}{b}
$$

in which: $\mathrm{a}=$ nutrient contribution of reference diet to nutrient content of test diet; $b=$ nutrient contribution of test ingredients to nutrient content of combined diet; $a+b=$ level of nutrient in combined $\operatorname{diet}(\%)$; ADCNtest $=$ apparent digestibility coefficient of a nutrient in combined diet; ADCNref $=$ apparent digestibility coefficient of a nutrient in reference diet

The trial consisted of eight treatments (test diets) and four replications (group of fish) arranged in a randomized block design for dry matter and gross energy ADC and three replications for mineral availability. The block was considered as a round of fecal collection. The differences between ingredients were analyzed according to the following model: $Y i j k=\mu+T i+B j+e i j k$

in which $Y$ is the observed response; $\mu$ the overall mean; $\mathrm{T}$ the effect of ingredients; $B$ the effect of the fecal collection period; and e is the residual error.

Aiming to facilitate the comparison between feedstuffs the ingredients were divided in two groups: plant proteinrich products and animal products. The ADC for dry matter, energy, and minerals among the tested ingredients were submitted to one-way ANOVA using the PROC GLM procedure of SAS (Statistical Analysis Sytem, version 8.12). Differences in ADC between the tested ingredients were determined using Tukey's multiple range test. Ingredient effects were considered significant at $\mathrm{P}<0.05$. No effect of the fecal collection period was observed. Additionally, the ADC data of all test diets were analyzed together by linear correlation using the PROC CORR procedure of SAS to investigate nutrient interaction.

\section{Results}

The ADC of DM was highly variable and ranged from 0.251 to 0.862 and 0.476 to 0.811 for plant and animal products, respectively (Table 3 ).

Similarly, ADC of energy was highly variable for all protein sources, although animal products tended to present less variation among all products. The ADC of energy ranged from 0.324 to 0.881 and 0.652 to 0.888 for plant and animal products, respectively.

Poultry by-product meal and corn gluten meal had the highest dry matter and energy digestibility values, while meat and bone meal and cottonseed meal at $280.0 \mathrm{~g} / \mathrm{kg}$ showed the lowest values (Table 4). Negative correlation was observed between crude fiber and ADC of dry matter and energy (-0.987 and -0.990 , respectively) in plant products, while inversely correlation was observed between ADC of $\mathrm{DM}$ and $\mathrm{Ca}, \mathrm{P}$ and ash content $(-0.829,-0.812$ and -0.698 , respectively) in animal products. Moreover, ADC values of dry matter and energy were positively correlated (0.993).

Overall, mineral availability was highly variable among all protein sources, although animal products presented 
higher availability values than plant sources (Table 5). Due to the lack of samples for mineral analysis, data on mineral availability for CGM are not shown.

The highest availability value was recorded for magnesium $(\mathrm{Mg})$ in poultry by-product meal $(0.857)$, while the lowest values were recorded for $\mathrm{Ca}$ and $\mathrm{Cu}$ in cottonseed meal at $280.0 \mathrm{~g} / \mathrm{kg}(-0.702)$ and poultry feather meal (-0.489), respectively. Among all minerals, the highest availability values were recorded for $\mathrm{Mg}$ and its availability was highly positively correlated to the $\mathrm{Ca}$ and ash contents in plant products, while in animal products it was positive and negatively correlated to $\mathrm{P}$ availability and ash content, respectively.
All plant products had negative availability coefficients for $\mathrm{Ca}$, while only $\mathrm{Cu}$ had negative values in poultry feather meal among the animal sources. Additionally, negative values were already recorded for $\mathrm{P}$ and $\mathrm{Cu}$ in cottonseed meal at $380.0 \mathrm{~g} / \mathrm{kg}$.

Phosphorus availability was higher in poultry byproduct meal (0.677) compared with the other animal sources, while fish meal and poultry feather meal had the lowest values ( 0.168 and 0.154 , respectively). In plant products, soybean showed the highest $\mathrm{P}$ availability, while cottonseed meal at $380.0 \mathrm{~g} / \mathrm{kg}$ showed the lowest value.

Table 3 - Apparent digestibility coefficients of dry matter and energy from protein-rich ingredients for Nile tilapia $(\mathrm{n}=4$ aquaria)

\begin{tabular}{|c|c|c|c|c|c|c|c|c|}
\hline \multirow[b]{2}{*}{ Nutrient } & \multicolumn{4}{|c|}{ Plant protein-rich products } & \multicolumn{4}{|c|}{ Animal by-products } \\
\hline & SBM & CGM & CSM28 & CSM38 & MBM & FM & PBM & PFM \\
\hline Dry matter & $0.578 \pm 0.023 b$ & $0.862 \pm 0.021 \mathrm{a}$ & $0.251 \pm 0.022 \mathrm{~d}$ & $0.352 \pm 0.021 \mathrm{c}$ & $0.476 \pm 0.019 \mathrm{D}$ & $0.666 \pm 0.025 \mathrm{C}$ & $0.811 \pm 0.022 \mathrm{~A}$ & $0.729 \pm 0.029 \mathrm{~B}$ \\
\hline Gross energy & $0.642 \pm 0.019 b$ & $0.881 \pm 0.015 \mathrm{a}$ & $0.324 \pm 0.015 \mathrm{~d}$ & $0.449 \pm 0.013 \mathrm{c}$ & $0.652 \pm 0.010 \mathrm{C}$ & $0.754 \pm 0.018 \mathrm{~B}$ & $0.888 \pm 0.009 \mathrm{~A}$ & $0.731 \pm 0.014 \mathrm{~B}$ \\
\hline
\end{tabular}

SBM - soybean meal; CGM - corn gluten meal; CSM28 - cottonseed meal at $280.0 \mathrm{~g} / \mathrm{kg}$; CSM 38 - cottonseed meal at $380.0 \mathrm{~g} / \mathrm{kg}$; MBM - meat and bone meal; FM - fish meal; PBM - poultry by-product meal; PFM - poultry feather meal.

Mean \pm standard deviation. Different letters within a row indicate significant differences at $\mathrm{P}<0.05$ by Tukey's test. Capital letters are for comparison of animal proteins and lowercase letters are for plant protein-rich ingredients.

Table 4 - Interaction between nutrient content and digestibility or availability of protein ingredients for Nile tilapia $(\mathrm{n}=3)$

\begin{tabular}{|c|c|c|c|c|c|c|}
\hline Nutrient & $\mathrm{ADC} \mathrm{DM}$ & $\mathrm{ADC} \mathrm{GE}$ & $\mathrm{ADC} \mathrm{Ca}$ & $\mathrm{ADC} \mathrm{Mg}$ & ADC $\mathrm{P}$ & $\mathrm{ADC} \mathrm{Cu}$ \\
\hline & \multicolumn{6}{|c|}{ Plant protein-rich products } \\
\hline Crude fiber & - $0.98 * *$ & $-0.99 * *$ & - & - & - & - \\
\hline Ash & - & - & $0.91 * *$ & $0.95 * *$ & 0.65 & 0.21 \\
\hline Phosphorus & - & - & -0.55 & $-0.93 * *$ & $-0.95 * *$ & $-0.70 *$ \\
\hline Magnesium & - & - & $-0.80 * *$ & $-0.98 * *$ & $-0.79 * *$ & -0.41 \\
\hline Copper & - & - & 0.25 & -0.40 & $-0.84 * *$ & $-0.99 * *$ \\
\hline Ash & $-0.70 *$ & -0.40 & 0.21 & -0.52 & 0.11 & $0.94 * *$ \\
\hline Calcium & $-0.83 * *$ & -0.57 & 0.16 & $-0.66^{*}$ & 0.07 & $0.92 * *$ \\
\hline Phosphorus & $-0.81 * *$ & -0.53 & 0.29 & $-0.61 *$ & 0.20 & $0.94 * *$ \\
\hline Magnesium & $-0.58 *$ & -0.26 & 0.27 & -0.40 & 0.17 & $0.94 * *$ \\
\hline Copper & -0.13 & -0.42 & -0.40 & -0.29 & -0.31 & $-0.60 *$ \\
\hline
\end{tabular}

DM - dry matter; GE - gross energy; Ca - calcium; Mg - magnesium; P - phosphorus; Cu - copper.

Each value represents a correlation coefficient $(n=9-16$ diets $)$ between dietary concentration of a nutrient and digestibility (availability). One and two asterisks values are statistically significant at $\mathrm{P}<0.05$ and $\mathrm{P}<0.01$ by the $\mathrm{F}$ test, respectively.

Table 5 - Apparent mineral availability of test ingredients for Nile tilapia $(\mathrm{n}=3$ aquaria)

\begin{tabular}{|c|c|c|c|c|c|c|c|}
\hline Mineral & \multicolumn{3}{|c|}{ Plant protein-rich products } & \multicolumn{4}{|c|}{ Animal products } \\
\hline Calcium & $-0.077 \pm 0.030 \mathrm{a}$ & $-0.702 \pm 0.032 \mathrm{c}$ & $-0.373 \pm 0.019 b$ & $0.351 \pm 0.032 \mathrm{~B}$ & $0.059 \pm 0.008 \mathrm{C}$ & $0.699 \pm 0.068 \mathrm{~A}$ & $-0.054 \pm 0.016 \mathrm{D}$ \\
\hline Magnesium & $0.710 \pm 0.038 \mathrm{a}$ & $0.396 \pm 0.044 b$ & $0.351 \pm 0.020 \mathrm{~b}$ & $0.404 \pm 0.042 \mathrm{C}$ & $0.595 \pm 0.036 \mathrm{~B}$ & $0.857 \pm 0.027 \mathrm{~A}$ & $0.606 \pm 0.026 \mathrm{~B}$ \\
\hline Copper & $0.201 \pm 0.018 b$ & $0.253 \pm 0.015 \mathrm{a}$ & $-0.030 \pm 0.017 \mathrm{c}$ & $0.667 \pm 0.016 \mathrm{~A}$ & $0.267 \pm 0.010 \mathrm{~B}$ & $0.203 \pm 0.012 \mathrm{C}$ & $-0.489 \pm 0.016 \mathrm{D}$ \\
\hline
\end{tabular}

SBM - soybean meal; CSM28 - cottonseed meal at $280.0 \mathrm{~g} / \mathrm{kg} ; \mathrm{CSM} 38$ - cottonseed meal at $380.0 \mathrm{~g} / \mathrm{kg} ;$ MBM - meat and bone meal; FM - fish meal; PBM - poultry by-produc meal; PFM - poultry feather meal.

Mean \pm standard deviation. Different letters within a row indicate significant differences at $\mathrm{P}<0.05$ by Tukey's test. Capital letters are for comparison of animal proteins and lowercase letters are for plant protein-rich ingredients. 


\section{Discussion}

The dry matter ADC estimates the amount of solid waste released to the environment and could be used to rate the gross environmental impact in aquaculture production. The main impact of solid waste (organic matter) is the deterioration of soil quality by anaerobic fermentation, which changes or destroys indigenous fauna of benthic ecosystems of the local environment (Sugiura et al., 2000). The results of DM digestibility for plant products in this study were generally lower than those reported for Nile tilapia elsewhere (Köprücü \& Özdemir, 2005; Gonçalves \& Furuya, 2004; Pezzato et al., 2002; Boscolo et al., 2002). Great differences between these studies and the present research were mainly observed for cottonseed meal products and soybean meal, while corn gluten meal presented slightly lower values in this study. The lower DM ADC of soybean meal could be explained by the higher crude fiber (CF) content of the product evaluated in this study $(71.0 \mathrm{~g} / \mathrm{kg})$ compared with those studies $(39.0 \mathrm{~g} / \mathrm{kg})$. This hypothesis is supported by the negative correlation between the CF content and the DM ADC observed in this study and previously reported by several authors (Hilton et al., 1983; Kirchgessner et al., 1986; McGoogan \& Reigh, 1996; Gaylord \& Gatlin III, 1996; Sugiura et al., 1998; Sklan et al., 2004).

It must be emphasized that in high extrusion conditions (high temperature and pressure), reaction between lipids and several types of carbohydrates could take place, forming insoluble compounds which reduce the availability of nutrients. Thus, the low DM digestibility in this study may have been affected by extrusion conditions which, associated with the content of fiber ingredients, contributed to drastically reduce the ADC values in plant protein-rich products.

Lower DM ADC were observed for animal products in this study compared with data reported for red drum (Sciaenops ocellatus) (Gaylord \& Gatlin III, 1996), salmon coho, rainbow trout (Sugiura et al., 1998) and tilapia (Köprücü \& Özdemir, 2005). Conversely, higher ADC values were reported for Nile tilapia fed pelleted diets (Pezzato et al., 2002). Similar values were reported for fish meal in rainbow trout (Sugiura et al., 2000), red drum (McGoogan \& Reigh, 1996) and piavuçu (Leporinus macrocephalus) (Gonçalves \& Furuya, 2004).

Variable results have been reported for animal protein sources. The quality of animal products may vary considerably according to the processing methods of raw materials and the relative quantity of waste products that comprises the meal (Dong et al., 1993). Anatomical and physiological differences between species have been already pointed out as the main factor for differences between digestibility studies (Cho \& Bureau, 2001). Thus, the higher values reported by Gaylord \& Gatlin III (1996) and Sugiura et al. (1998) could be a species-related effect, since carnivorous fish are able to digest some animal protein products (mainly bones, connective tissues and chitin) better than omnivorous/herbivorous fish. The lower DM digestibility values obtained for fish meal and meat and bone meal could be due to the high bone content of these meals. It has been demonstrated that increasing amounts of bones in animal products meal linearly reduce nutrient availability (Sugiura et al., 2000). This supports the results of this study, in which a significantly inverse correlation $(\mathrm{r}=-0.698, \mathrm{P}<0.05)$ was observed between ash content and DM digestibility. Although bone content of the meals was not measured, it is supposed that these meals have high bone content due the high $\mathrm{Ca}, \mathrm{P}$ and $\mathrm{Mg}$ content, since bones are basically constituted by these minerals. High correlation between ash and bone content of ingredients has been previously reported (Sugiura et al., 1998; Hertrampf \& Piedad-Pascual, 2003).

The higher digestibility values obtained in this study for DM compared with those reported by Pezzato et al. (2002) may be related to the extrusion effect. Our results were generally $10 \%$ higher than those, except for meat and bone meal, which presented similar values and poultry feather meal, which was $35 \%$ higher in our study. It has been reported that protein complexes in various ingredients of a diet under high heat, pressure and shear forces of extrusion process are denatured and plasticized, making them more susceptible to digestible to digestive process which concur for an increase in overall ingredients digestibility (Botting, 1991).

Several studies have reported the correlation between DM and gross energy (GE) digestibility (Sugiura et al., 1998, 2000; MacGoogan \& Reigh, 1996; Gaylord \& Gatlin III, 1996). This effect could already be related to the lipid content of feedstuffs, since in this study the ingredients which presented the highest digestibility values had the highest lipid contents.

The calcium availability of the different feedstuffs determined in this study varied considerably but was comparable to the values reported for other fish species in animal products (NRC, 1993; Sugiura et al. 1998, 2000). On the other hand, higher $\mathrm{Ca}$ availability values have been reported for soybean meal and fish meal in tilapia (Furuya et al., 2001). 
Although several studies have reported nutrient digestibility for different feed ingredients for cultured fish species, studies regarding the mechanisms which control mineral absorption or mineral availability are still scarce. Thus, this study observed that in tilapia, as in other fish species, $\mathrm{Ca}$ availability should be influenced by water borne $\mathrm{Ca}$ content. It has been reported that tilapia and other fish species rely more on water $\mathrm{Ca}$ absorption from the gills than from the intestinal epithelia (Flik et al., 1993; Flik \& Verbost, 1993), although the factors which regulate these mechanisms are still unknown and seem to be very complex involving several hormones and interaction with other minerals.

Negative values for $\mathrm{Ca}$ availability have been previously reported in the literature for several fish species, including tilapia (Gonçalves et al., 2005; Sugiura et al., 1998; Vielma \& Lall, 1997). Calcium availability values were assumed to be influenced by other dietary factors present in plant protein products. This hypothesis is confirmed by all the negative and lower values observed in this group of ingredients. Plant products, especially oilseed cakes, usually have a certain amount of anti-nutritional factors which could affect nutrient utilization and, consequently, animal growth performance in different degrees according to the type and amount of the compound. It has been reported that phytates, fiber and other ligands present in plant ingredients reduce the Ca availability (Champagne, 1989; Sugiura et al., 1998) and/or endogenous loss.

According to Sugiura et al. (1998, 2000), negative availability values must be due to interactions between the test ingredient and basal (reference) diet. However, the negative value does not indicate a negative balance of nutrients, but an antagonistic property of the test ingredient for the absorption of nutrients in diets. These authors already observed that this pattern of values below the "theoretical minimum" was more common with $\mathrm{Ca}, \mathrm{Cu}, \mathrm{Fe}$, $\mathrm{Mn}, \mathrm{Na}, \mathrm{Sr}$ and $\mathrm{Zn}$ than with $\mathrm{Mg}$. This observation is in accordance with the results of this study, in which only one negative value was observed for $\mathrm{Mg}$, while more negatives values were observed for $\mathrm{Ca}$ and $\mathrm{Cu}$ in this study.

Between 50 to $80 \%$ of the $\mathrm{P}$ present in plant products is in the phytic form and this compound has the ability to strongly chelate di- and trivalent minerals such as $\mathrm{Ca}, \mathrm{Co}$, $\mathrm{Fe}, \mathrm{Mg}, \mathrm{Mn}$ and $\mathrm{Zn}$, reducing their availability for monogastric animals (Wise, 1983; Ravindran et al., 1995; Pallauf \& Rimbach, 1996). Thus, according to the negative correlation between the $\mathrm{P}$ content and the apparent availability of $\mathrm{P}, \mathrm{Mg}$ and $\mathrm{Cu}$ observed in this study, it could be demonstrated that the phytates were probably responsible for the reduced mineral availability in plant products. However, no significant correlation was observed for Ca availability.

Additionally, the negative values observed for cottonseed meal at $380 \mathrm{~g} / \mathrm{kg}$ must be due to the combined effects of gossypol and fiber content of this ingredient, although the fiber content in this ingredient was lower than cottonseed meal at $280 \mathrm{~g} / \mathrm{kg}$. Differences in the mealprocessing methods could be one of the factors that explain the variability in the cottonseed meal nutrient digestibility, regardess of the fiber content (Guimarães et al., 2008).

Although Sugiura et al. (1998) have reported similar P availability values for soybean meal $(0.284$ and 0.220$)$ and poultry by-product meal ( 0.677 and 0.635$)$, higher values were obtained for fish meal ( 0.573 and 0.444$)$ and poultry feather meal $(0.754$ and 0.617$)$ in rainbow trout and salmon coho, respectively. Phosphorus availability was reported to be higher for soybean meal (0.471) and fish meal (0.488) in tilapia (Furuya et al., 2001).

The low P apparent availability and respectively high variability in animal products are related to the quality of raw materials used to produce these by-products. Additionally, the lower P availability in fish meal could be related to the bone content of the ingredient. It has been previously reported that bone mineral appears to depress the ADC and apparent availability of many minerals and bone $\mathrm{P}$ absorption present a plateau which could be related to the limited ability of some fish species to digest bone $\mathrm{P}$ at high dietary levels (Sugiura et al., 2000). Although the bone content of the animal products was not measured, the $\mathrm{Ca}, \mathrm{Mg}$ and ash content indicated that meat and bone meal and fish meal presented the highest bone contents among the products evaluated. However, P availability was higher in meat and bone meal even presenting higher ash content than fish meal. This effect must be due to different bone particle sizes between these products, as previously reported for rainbow trout (Vielma et al., 1999).

Several studies have emphasized differences in digestibility assays and caution must be taken when comparing data from different studies, since factors such as the feces collection procedure, calculation method and fish species could influence the results of digestibility. Moreover, differences in the feed processing method could affect the results by reducing the amount of some anti-nutritional factors presented in some plant products (Cheftel, 1986) or by increasing the amount of insoluble compounds which could damage nutrient availability. However, studies regarding the effects of feed processing methods on mineral availability in fish are still scarce.

The high availability of $\mathrm{Mg}$ observed in this study is in accordance with data reported with salmon and rainbow 
trout (Sugiura et al., 1998, 2000; Cheng \& Hardy, 2003) and Nile tilapia (Gonçalves et al., 2005). Higher Mg availability is expected in tilapia, since this species relies more on intestinal absorption of $\mathrm{Mg}$ ( $80 \%$ of total $\mathrm{Mg}$ absorption) than from gills. Moreover, an inverse correlation between $\mathrm{Mg}$ availability and $\mathrm{Ca}$ and $\mathrm{P}$ content was observed in the diets for animal products. These results are in accordance with those reported by Sugiura et al. $(1998,2000)$ with rainbow trout. Conversely, in plant protein products, the $\mathrm{Mg}$ availability was positively correlated to $\mathrm{Ca}$ content in the diets. This effect should be due to the low Ca levels in these ingredients and since in basal levels the absorption of $\mathrm{Mg}$ is coupled with $\mathrm{Ca}$ and sodium, this might have influenced this result.

Finally, studies are needed to better understand the mechanisms which regulate mineral absorption in different environmental conditions and how dietary factors could influence their availability.

\section{Conclusions}

Nile tilapia is able to efficiently utilize minerals from animal by-products better than plant protein products, and the poultry by-product meal seems to be an interesting ingredient to compound diets for this species due to its higher nutrient digestibility and $\mathrm{P}$ availability, contributing to reduction of waste outputs in aquaculture production.

\section{Acknowledgements}

This research is part of Master dissertation of the first author and was financially supported by Mogiana Alimentos S.A. and Conselho Nacional de Desenvolvimento Científico e Tecnológico (CNPq, Brazil). We also thank graduate students Leonardo Tachibana and Giovani Sampaio Gonçalves for the technical support in the conduction of the experiment.

\section{References}

ASSOCIATION OF OFFICIAL AGRICULTURAL CHEMISTS AOAC. Official methods of analysis. 15.ed. Arlington: AOAC International, 1995. 1025p.

BOSCOLO, W.R.; HAYASHI, C.; MEURER, F. Digestibilidade aparente da energia e nutrientes de alimentos convencionais e alternativos para a tilápia do nilo (Oreochromis niloticus, L.). Revista Brasileira de Zootecnia, v.31, p.539-545, 2002.

BOTTING, C.C. Extrusion technology in aquaculture feed processing. In: AKIYAMA, D.M.; TAN, R.K.H. (Eds.). In: AQUACULTURE FEED PROCESSING AND NUTRITION WORKSHOP, Thailand and Indonesia. Proceedings... Republic of Singapore: American Soybean Association, 1991. p.129-137.

BREMER-NETO, H.; GRANER, C.A.F.; PEZZATO, L.E. et al. Determinação de rotina do crômio em fezes, como marcador biológico, pelo método espectrofotométrico ajustado da 1,5difenilcarbazida. Ciência Rural, v.35, p.691-697, 2005.

CHAMPAGNE, E.T, Low gastric hydrochloric acid secretion and mineral bioavailability. In: DINTZIS, F.R.; LASZLO, J.A. (Eds.) Mineral absorption in the monogastric GI tract. New York: Plenum Press, 1989. p.173-184.

CHEFTEL, J.C. Nutritional effects of extrusion-cooking. Food Chemistry, v.20, p.263-283, 1986

CHENG, Z.J.; HARDY, R.W. Effects of extrusion processing of feed ingredients on apparent digestibility coefficients of nutrients for rainbow trout (Oncorhynchus mykiss). Aquaculture Nutrition, v.9, p.77-83, 2003

CHO, C.Y. Digestibility of feedstuffs as a major factor in aquaculture waste management. In: KAUSHIK, S.J.; LAQUET, P. (Eds.) Fish nutrition in practice. Paris: INRA, 1993. p.363-374.

CHO, C.Y.; BUREAU, D.P. A review of diet formulation strategies and feeding systems to reduce excretory and feed wastes in aquaculture. Aquaculture, v.32, p.349-360, 2001.

DONG, F.M.; HARDY, R.W.; HAARD, N.F. et al. Chemical composition and protein digestibility of poultry by-product meals for salmonid diets. Aquaculture, v.116, p.149-158, 1993.

FLIK, G.; VAN DER VELDEN, J.A.; DECHERING, K.J. et al. $\mathrm{Ca}^{2+}$ and $\mathrm{Mg}^{2+}$ transport in gills and gut of Tilapia, Oreochromis mossambicus: a review. Journal of Experimental Biology, v.265, p.356-365, 1993.

FLIK, G.; VERBOST, P.M. Calcium transport in fish gills and intestine. Journal of Experimental Biology, v.184, p.17-29, 1993.

FORSTER, I. A note on the method of calculating digestibility coefficients of nutrients provided by single ingredients to feeds of aquatic animals. Aquaculture Nutrition, v.5, p.143-145, 1999

FURUYA, W.M.; PEZZATO, L.E.; PEZZATO, A.C. et al. Coeficientes de digestibilidade e valores de aminoácidos digestíveis de alguns ingredientes para tilápia do nilo (Oreochromis niloticus). Revista Brasileira de Zootecnia, v.30, p.1143-1149, 2001.

GAYLORD, T.G.; GATLIN III, D.M. Determination of digestibility coefficients of various feedstuffs for red drum (Sciaenops Ocellatus). Aquaculture, v.139, p.303-314, 1996.

GONÇALVES, G.S.; FURUYA, W.M. Digestibilidade aparente de alimentos pelo piavuçu, Leporinus macrocephalus. Acta Scientiarum. Animal Sciences, v.26, p.165-169, 2004.

GONÇALVES, G.S.; PEZZATO. L.E.; BARROS, M.M. et al. Efeitos da suplementação de fitase sobre a disponibilidade aparente de $\mathrm{Mg}, \mathrm{Ca}, \mathrm{Zn}, \mathrm{Cu}, \mathrm{Mn}$ e $\mathrm{Fe}$ em alimentos vegetais para a tilápia-do-nilo. Revista Brasileira de Zootecnia, v.34, p.2155-2163, 2005.

GUIMARÃES, I.G.; PEZZATO, L.E.; BARROS, M.M. Amino acid availability and protein digestibility of several protein sources for Nile tilapia, Oreochromis niloticus. Aquaculture Nutrition, v. 14, p.396-404, 2008.

HEPHER, B. Nutrition of pond fishes. New York: Cambridge University Press, 1988. 404p.

HERTRAMPF, J.C.; PIEDAD-PASCUAL, F. Handbook on ingredients for aquaculture feeds. The Netherlands: Kluwer Academic Publishers, 2003. 628p.

DE LA HIGUERA, M. Diseños e métodos experimentales de evaluación de dietas. In: MONTEROS, J.A.E.; LABARTA, M. (Eds.). Nutrición en Acuicultura II. Madrid: Comisión Asesora de Ivestigación Científica y Tecnica, 1987. p.291-318.

HILTON, J.W.; ATKINSON, J.L.; SLINGER, S.J. Effect of increased dietary fiber on the growth of rainbow trout (Salmo gairdneri). Canadian Journal of Fisheries Aquatic Science, v.40, p. 81-85, 1983 .

HUA, K.; DE LANGE, C.F.M.; NIIMI, A.J. et al. A factorial model to predict phosphorus waste output of rainbow trout (Oncorhynchus mykiss). Aquaculture Research, v.39, p.1059-1068, 2008.

KIRCHGESSNER, M.; KURZINGER, H.; SCHWARZ, F.J. Digestibility of crude nutrients in different feeds and estimation of their energy contents for carp (Cyprinus carpio L.). Aquaculture, v.58, p.185-194, 1986. 
KOPRUCU, K.; OZDEMIR, Y. Apparent digestibility of selected feed ingredients for Nile tilapia (Oreochromis niloticus). Aquaculture, v.250, p.308-316, 2005.

MACMILLAN, J.R.; HUDDLESTON, T.; WOOLEY, M. et al. Best management practice development to minimize environmental impact from large flow-through trout farms. Aquaculture, v.226, p.91-99, 2003.

MCGOOGAN, B.B.; REIGH, R.C. Apparent digestibility of selected ingredients in red drum (Sciaenops ocellatus) diets. Aquaculture, v.141, p.233-244, 1996.

NATIONAL RESEARCH COUNCIL - NRC. Nutrient requirements of fish. Washington, D.C.: National Academy Press, 1993. 105p.

PALLAUF, J.; RIMBACH, G. Effect of supplemental phytase on mineral and trace element bioavailability and heavy metal accumulation in pigs with different type diets. In: COELHO, M.B.; KORNEGAY, E.T. (Eds.) Phytase in animal nutrition and waste management. Mount Olive: BASF Corporation, 1996. p.451-465.

PERSSON G. Eutrophication resulting from salmonid fish culture in fresh and salt waters: Scandinavian experiences. In: INTERNATIONAL SYMPOSIUM ON NUTRITIONAL STRATEGIES IN MANAGEMENT OF AQUACULTURE WASTE, 1., 1991, Ontario. Proceedings... Ontario: University of Guelph, Nutritional Strategies and Aquaculture Waste, 1991. p.163-185.

PEZZATO, L.E.; DE MIRANDA, E.C.; BARROS, M.M. et al. Digestibilidade aparente de ingredientes pela tilápia do nilo (Oreochromis niloticus). Revista Brasileira de Zootecnia, v.31, p.1595-1604, 2002.

PIMENTEL-RODRIGUES, A.; OLIVA-TELES, A. Phosphorus availability of inorganic phosphates and fish meals in European sea bass (Dicentrarchus labrax L.) juveniles. Aquaculture, v.267, p.300-307, 2007.

PORTZ, L.; LIEBERT, F. Growth, nutrient utilization and parameters of mineral metabolism in Nile tilapia Oreochromis niloticus
(Linnaeus, 1758) fed plant-based diets with graded levels of microbial phytase. Journal of Animal Physiology and Animal Nutrition, v.88, p.311-320, 2004.

POWERS-HUGHES, K.; SOARES JR., J.H. Efficacy of phytase on phosphorus utilization in pratical diets fed to striped bass Morone saxatilis. Aquaculture Nutrition, v.4, p.133-140, 1998.

RAVINDRAN, V.; BRYDEN, W.L.; KORNEGAY, E.T. Phytin: Occurrence, bioavailability and implications in poultry nutrition. Poultry and Avian Biology Reviews, v.6, p.125-143, 1995.

SKLAN, D.; PRAG. T.; LUPATSCH, I. Apparent digestibility coefficients of feed ingredients ant their prediction in diets for tilapia Oreochromis niloticus x Oreochromis aureus (Teleostei, Cichlidae). Aquaculture Research, v.35, p.358-364, 2004.

SUGIURA, S.H.; BABBITT, J.K.; DONG, F.M. et al. Utilization of fish and animal by-product meals in low-pollution feeds for rainbow trout Oncorhynchus mykiss (Waulbaum). Aquaculture Research, v.31, 585-593. 2000

SUGIURA, S.H.; DONG, F.M.; RATHBONE, C.K. et al. Apparent protein digestibility and mineral availabilities in various feed ingredients for salmonid feeds. Aquaculture, v.159, p.177-202, 1998.

SUGIURA, S.H.; MARCHANT, D.D.; KELSEY, K. et al. Effluent profile of commercially used low-phosphorus fish feeds. Environmental Pollution, v.140, p.95-101, 2006.

TACON, A.G.J.; FORSTER, I.P. Aquafeeds and the environment: policy implications. Aquaculture, v.226, p.181-189, 2003.

VIELMA, J.; LALL, S.P. Dietary formic acid enhances apparent digestibility of minerals in rainbow trout, Oncorhynchus mykiss (Walbaum). Aquaculture Nutrition, v.3, p.265-268, 1997.

VIELMA, J.; RUOHONEN, K.; LALL, S.P. Supplemental citric acid and particle size of fish bone-meal influence the availability of minerals in rainbow trout Oncorhynchus mykiss (Waulbaum). Aquaculture Nutrition, v.5, p.65-71, 1999.

WISE, A. Dietary factors determining the biological activities of phytase. Nutrition Abstracts and Reviews, v.53, p.791-806, 1983. 